\title{
Probing the Pharmacological Binding Properties, and Reactivity of Selective Phytochemicals as Potential HIV-1 protease Inhibitors
}

\author{
Ammara Akhtar ${ }^{1}$ Waqar Hussain ${ }^{2}$, Nouman Rasool ${ }^{3, *}$
}

Edited by

Juan Carlos Salcedo-Reyes

(salcedo.juan@javeriana.edu.co)

1. University of Management and Technology, Department of Life Sciences, Lahore-54770, Pakistan.

2. University of the Punjab, National Center of Artificial Intelligence, Punjab University College of Information and Technology, Lahore-54000, Pakistan.

3. University of Karachi, Karachi-75270, Dr Panjwani Center for Molecular Medicine and Drug Research, International Center for Chemical and Biological Sciences, Pakistan.

*noumanrasool@gmail.com

Received: 23-07-2018

Accepted: 13-06-2019

Published on line: 02-10-2019

Citation: Akhtar A, Hussain W, Rasool N. Probing the Pharmacological Binding Properties, and Reactivity of Selective Phytochemicals as Potential HIV-1 protease Inhibitors,

Universitas Scientiarum, 24 (3): 441-464, 2019. doi: 10.11144/Javeriana.SC24-3.artf

Funding:

N.A.

Electronic supplementary material: N.A.

OPEN ACCESS

\section{Abstract}

The HIV-1 protease plays an essential role in the replication cycle of HIV-1; therefore there is a direct need to develop novel inhibitors of the HIV-1 protease, which can cease the viral replication. The present study targets the discovery of potential inhibitors of HIV-1 protease from a set of phytochemicals. From 2505 phytochemicals, 108 compounds were docked, after screening, with the HIV-1 protease to analyze their inhibitory potential against the protease. DFT analysis was also conducted to study the reactivity of strongly docked compounds. Out of 108 phytochemicals, 38 compounds showed binding affinity greater than the desired threshold. Reactivity of these 38 inhibitors was also high as compared to other compounds, based on the DFT results. These results suggest that the selected 38 phytochemicals are drug candidates and they have the potential to be effectively used against HIV in the future.

Keywords: HIV-1; protease; phytochemicals; molecular docking; DFT; ADMET.

\section{Introduction}

The human immunodeficiency virus is the main cause of acquired immunodeficiency syndrome around the world [1, 2]. HIV is predominately a sexually transmitted disease globally, but infection can also be transmitted from one person to another by blood, from mother to fetus etc. When a virus invades, it replicates rapidly in the body. As the concentration of viral load increases in the body, it is followed by a steady decrease in the level of CD4+ T lymphocyte [3]. As the immune system becomes weak, the body is exposed to several opportunistic infections and neoplasm, which lead to ultimate death. According to a report presented by UNAID (the Joint United Nations program on HIV/ AIDS) in the year 2003, there were 5 million cases of HIV infection around the world according to an estimated, while the death 
caused by HIV infection was 3 million. Because of the high mortality rate, it was considered the $4^{\text {th }}$ main cause of mortality cases globally [4]. In 2016, according to a report globally, approximately 36.7 million people were living with HIV infection and around 1 million people died because of complications of AIDS disease [5].Therefore, the immediate challenge is to reduce the high mortality and morbidity rate associated with AIDS disease.

The virus code for a protease named aspartic protease has a main role in the assembly as well as maturation of virion [6, 7]. Consequently, any compound that will inhibit protease ultimately helps in keeping the virus in its immature state. Protease can be inactivated by either introducing mutation or using a chemical inhibitor. The virus with a dysfunctional protease will be consequently non-infectious. The HIV protease inhibitors play an essential role in rational drug design against the deadly disease AIDS [6]. Recently the strategy used for the treatment of this viral infection is HAART (highly active anti-retroviral therapy). Drugs are made for general use in case of HIV infection on the basis of three groups such as protease inhibitors, nucleoside and non-nucleoside inhibitors of the reverse transcriptase of the HIV-1 virus. The prolonged application of these drugs is limited either because of their toxic effect or development of drug resistance with the passage of time [8-10]. Despite the fact that the antiviral therapy used against HIV-1 infection is effective, there is also an increase in drug resistance cases in infected patient due to high mutation rate or virus and several severe side effects. Hence, there is an immediate need for the search of new inhibitors against HIV-1 viral proteins [11].

The HIV-1 protease can be used as a promising target for designing drugs in antiviral therapy. The enzyme has an active site which can be said as an open-ended cylinder. The active site contains hydrophobic amino acids and the two catalytic sites of aspartic acids. Friedman et al. [12] reported that flavonoid compounds like $\mathrm{C}_{60}$ fullerene have the ability to bind with the active site of HIV-1 protease. The $\mathrm{C}_{60}$ has almost the same radius as compared to the cylinder radius of the active site of the HIV-1 protease, and also the $\mathrm{C}_{60}$ molecule is hydrophobic; thus, there is a high chance of interaction with the active site of the virus. Kinetic analysis of $\mathrm{C}_{60}$ derivative named bis- $\mathrm{C}_{60}$ with the HIV-1 protease exhibits a mode of inhibition [13].

Although ART (Anti-retroviral therapy) has been proved to be effective in slowing down the rate of HIV replication in the body, there are also serious side-effects in infected patients. The therapy may lead to lipodystrophy (LD). Lipodystrophy can be characterized by loss of fat in peripheral areas of the body. Central fat will then have started to accumulate, resulting in thin arms and legs, facial pads and pot belly; symptoms that left the patient stigmatized 
[14]. To avoid these side-effects, there is a need for producing non-nucleoside inhibitors. It would be rational to assume that the compounds extracted from plants having the non-nucleoside properties, can be used in anti-retroviral treatment [15].

Tewtrakul et al. [16] reported the extraction of four flavonoids (phytochemicals) from the rhizome of plant named Boesenbergia pandurata Holtt, which were tested for the inhibition of HIV-1 Protease. The four compounds separated were pinostrobin, cardamonin, pinocembrin and alpinetin. The result showed that cardamonin have inhibitory activity against HIV-1 protease with the inhibitory concentration of $50 \%\left(\mathrm{IC}_{50}\right)$ of $31 \mu \mathrm{g} / \mathrm{ml}$.

Screening of a vast variety of drugs in-vitro or in-vivo as potent inhibitors against several diseases is a costly and laborious task. With the advancement in the field of bioinformatics, in sillico analysis by using different computational methods is a highly efficient and cost-effective method. The phytochemicals hold a vast prospective to cure various bacterial and viral diseases. Screening of phytochemicals by computational method helps to screen the various phytochemical with high certainty and efficiency. The main objective of this study is to screen different phytochemicals as potential inhibitors against HIV-1 protease.

\section{Material and methods}

\section{Screening for phytochemicals collection}

By surveying different literature sites and retrieving information about the compounds extracted from plants from various sites, a total of 2505 phytochemicals were studied. Screening for phytochemicals collection were based on their properties in lowering the effects of many health-related issues. These natural compounds having medicinal properties like anti-viral, antibacterial, anti-fungal can be really helpful in treatment of several diseases [17]. The phytochemicals of specific plants were searched through literature, $2 \mathrm{~d}$ and $3 \mathrm{~d}$ structures of these compounds were obtained through PubChem.

\section{Molecular docking and estimation of binding energy}

To determine how these phytochemicals interact with HIV-1 protease on its active site, docking was performed using Auto Dock Tools and Auto Dock Vina. Through docking, binding properties of these compounds were studied. The protein structure of HIV-1 protease was taken from the RCSB PDB. The structures of HIV-1 protease and ligands were visualized through Chimera software. The model of the HIV-1 protease was prepared for docking by using 
Auto Dock Tools, and polar hydrogen bonds were added to optimize the interaction occurring between phytochemicals and HIV-1 protease. A 3D grid for HIV-1 protease with a size of $16 \times 12 \times 14 \AA$ was designed to describe the search space for phytochemicals $[18,19]$.

\section{ADMET and drug-like properties}

The phytochemicals were screened on the basis of their ADMET characteristics (absorption, distribution, metabolism, excretion and toxicity) and drug-like properties by using web-based predictor, preADMET server. Screening of different pharmacological and pharmacokinetics properties like gastrointestinal absorption (GI), solubility, blood-brain barrier permeability (BBB) of these naturally occurring compounds were studied. This in silico tool was used for the screening of lead compounds that have the potential to be used as therapeutic drugs against HIV-1 protease. The standards set for the screening of phytochemicals were: Solubility: High, GI absorption: High or moderate, BBB-permeability: No, Lipinski's violation: 0, Toxicity: 0/Nil [20]. Lipinski's rule of five was used to determine the drug-likeness properties of the phytochemicals.

\section{DFT analysis}

Density functional theory (DFT) analysis was done to study the phytochemicals reactivity properties and how efficiently they act when used against HIV-1 protease. The study was performed by using HOMO (highest occupied molecular orbital) and LUMO (lowest unoccupied molecular orbital) energies. The $\Delta \mathrm{E}$ (band energy gap) calculation was performed using the expression $\mathrm{E}_{\mathrm{LUMO}}-\mathrm{E}_{\mathrm{HOMO}}$. The Avogadro was used to prepare the input file, which is a chemical analyzer tool [21] and all the energy calculations were performed using the program named ORCA [22].

\section{Results}

\section{ADMET results}

All the 2505 phytochemicals were screened for their ADMET properties to determine if these compounds have the potential to produce any adverse side-effects in humans. Out of 2505 phytochemicals, a total 1061 compounds violated the Lipinski's rule. The remaining 1689 phytochemical were further screened on the basis of BBB (Blood-brain barrier) permeability. A total of 756 compounds were non-BBB permeable. Among these 756 compounds, 650 phytochemical exhibited high GI absorption and optimum solubility. Phytochemicals were further screened to check toxicity and carcinogenicity 
effects, and in the end, 108 phytochemicals were finally selected on the basis of their drug-likeness and ADMET properties.

\section{Docking of phytochemicals with HIV-1 protease}

In silico docking of all the 108 phytochemicals were done against HIV-1 protease to find out the binding energy and $\mathrm{Ki}$ (inhibitory constant) values based on their complex geometry. The results exhibited that all 108 phytochemicals expressed different characteristics while interacting with the HIV-1 protease. Different drugs reported previously and listed in Table 1 were docked, and the highest binding affinity was set as the threshold for screening docked compounds, i.e, $-7.9 \mathrm{kcal} / \mathrm{mol}$. Out of 108 phytochemicals, 38 compounds showed binding affinity values greater than $-7.9 \mathrm{kcal} / \mathrm{mol}$ and exhibited great potential in inhibiting the HIV-1 protease. The 38 compounds included Cannflavin, AmyrisinC, EryvarinP, Xylan, Fumaric acid, SigmoidinA, Derrisin, AmyrisinB, 3-oxo-14-deoxy-andrographolide, Oxysanguinarine, Paracrine, IsoerysenegalenseinE, Emodin, Ascorbic Acid, Raddeanine, Menisdaurin, Lenticin, IsosilybinA, Diprenyleriodictyol, SilybinA, Riboflavin, Fumaritine N-oxide, Feruloyltyramine, Wighteone, Robustone, SchizolaenoneB, Narlumidine, Luteolin, SigmoidinB, EryvarinM, Narlumicine, Hydroxymunduserone, Mundulinol, Adenosine, IsosilybinB, Praline, Cirsimaritin and Pyridoxine (Fig. 1; Table 2).

\section{DFT analysis and band energy gap results}

The DFT result showed that the 38 selected phytochemicals exhibited high reactivity. The low energy values ranging from $0.112 \mathrm{kcal} / \mathrm{mol}$ to $0.166 \mathrm{kcal} / \mathrm{mol}$ proved their high reactivity properties. The values of $\mathrm{E}_{\mathrm{LUMO}}$ and $\mathrm{E}_{\mathrm{HOMO}}$ were also low, exhibiting the fact that lower band energy gaps result in high affinity of the inhibitors for the target protein HIV-1 Protease. Among the 38 chemicals, AmyrisinC showed the highest reactivity against the HIV-1 protease, because the band energy exhibited was the lowest among all of the 38 phytochemicals, i.e, $0.112 \mathrm{kcal} / \mathrm{mol}$ (Table 2).

\section{Discussion}

HIV-1 protease is an important enzyme in the replication cycle of Human immunodeficiency virus (HIV), without it, the virion is not able to mature. The natural compounds have the potential to treat AIDS. HIV-1 protease inhibitors are widely studied as anti-AIDS drugs [23]. Clinical studies of these naturally occurring compounds also showed that these phytochemicals are safe for human consumption [24]. The natural compounds are also preferred 
Table 1. HIV synthetic inhibitors against HIV-1 Protease and their Binding affinity $(\mathrm{kcal} / \mathrm{mol})$.

COMPOUND

BINDING AFFINITY (kcal/mol)

\begin{tabular}{|cc|}
\hline Lopinavir & -7.9 \\
\hline Ritonavir & -7.7 \\
\hline Tipranavir & -5.5 \\
\hline Darunavir & -5.1 \\
\hline Nelfinavir & -4.6 \\
\hline Emtricitabine & -4.5 \\
\hline
\end{tabular}

because as compared to other chemically synthesized drugs, these compounds do not produce any side effect. Phytochemicals are usually obtained from different parts of the plant and include alkaloids, flavonoids, tannins and terpenoids. The HIV-1 protease has been also targeted by using different phytochemicals obtained from various plants. Phytochemicals obtained from the plant named Mappia foetida have been proved to have anticancer properties and antiviral activity. The compounds obtained from this plant can also effectively inhibit the HIV-1 Protease [23]. The 38 phytochemicals selected after in silico study showed that they have the capability to act as an effective drug against different diseases. These phytochemicals have been reported in different studies because of their effective inhibitory effects against a number of diseases. For example, Cannflavin isolated from plant Cannabis sativa $\mathrm{L}$. is a flavonoid that has been identified to have numerous health benefits. It has been reported to have antiviral properties, anti-inflammatory effects, cardioprotective, anticancer activities, antioxidant and antimicrobial effects. This compound can be used in the future for the effective drug designing against HIV-1 Protease [25]. Emodin has been previously reported to have antifungal and anti-bacterial properties. Emodin was also found to be efficiently active against fungal spore germination [26]. Several other phytochemicals reported in this study like Wighteone (flavonoid) [27], SchizolaenoneB (flavonoid) [28], Narlumidine, papraline and Narlumicine 


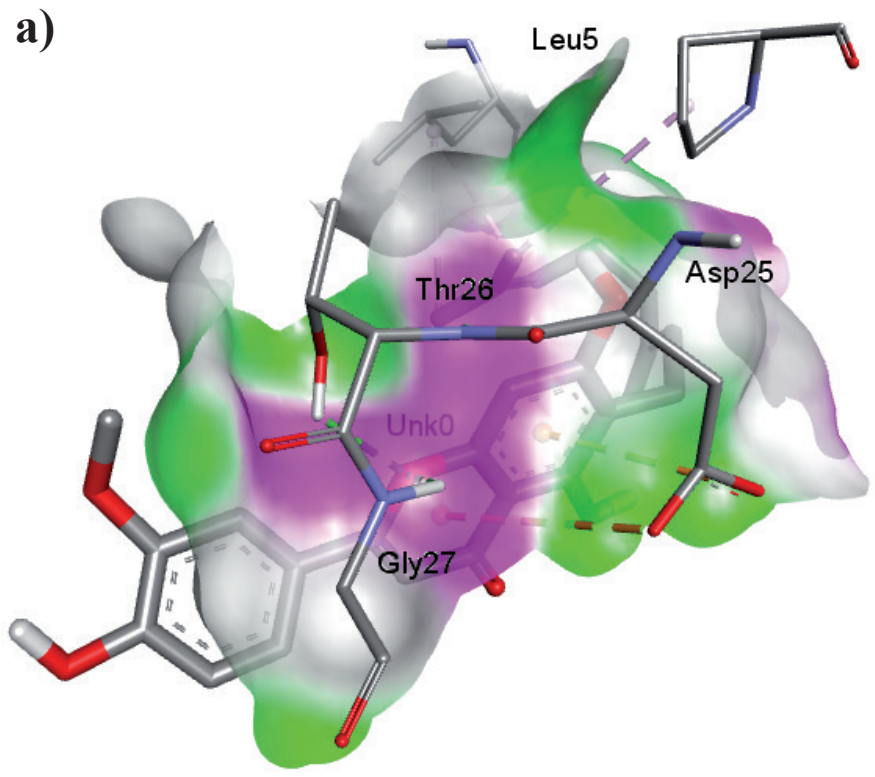

b)

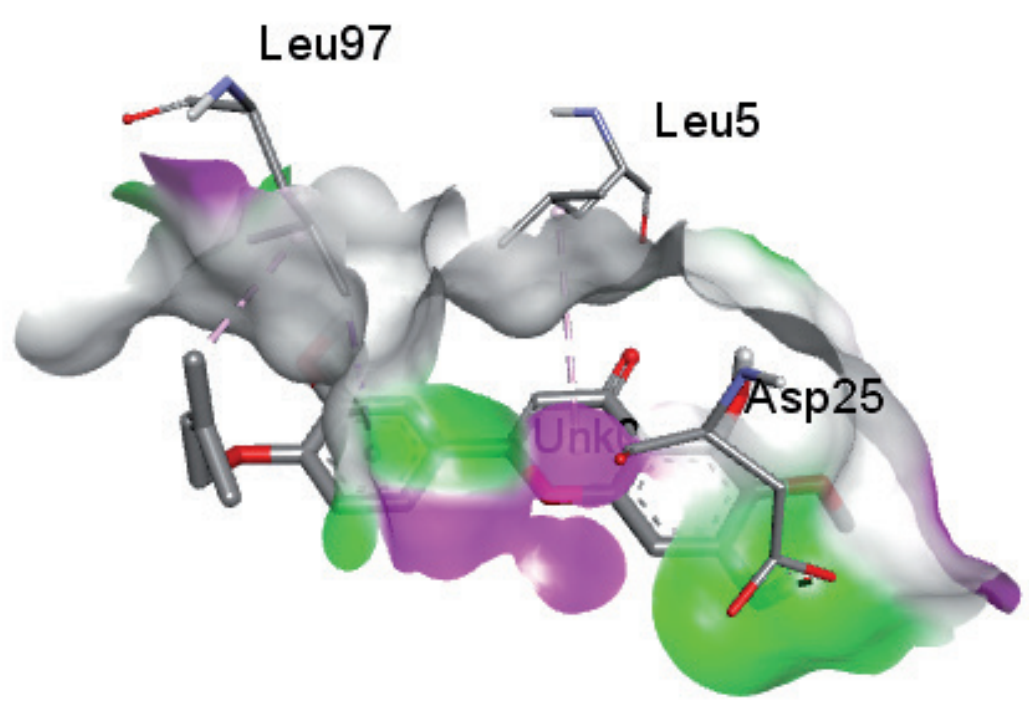

c)

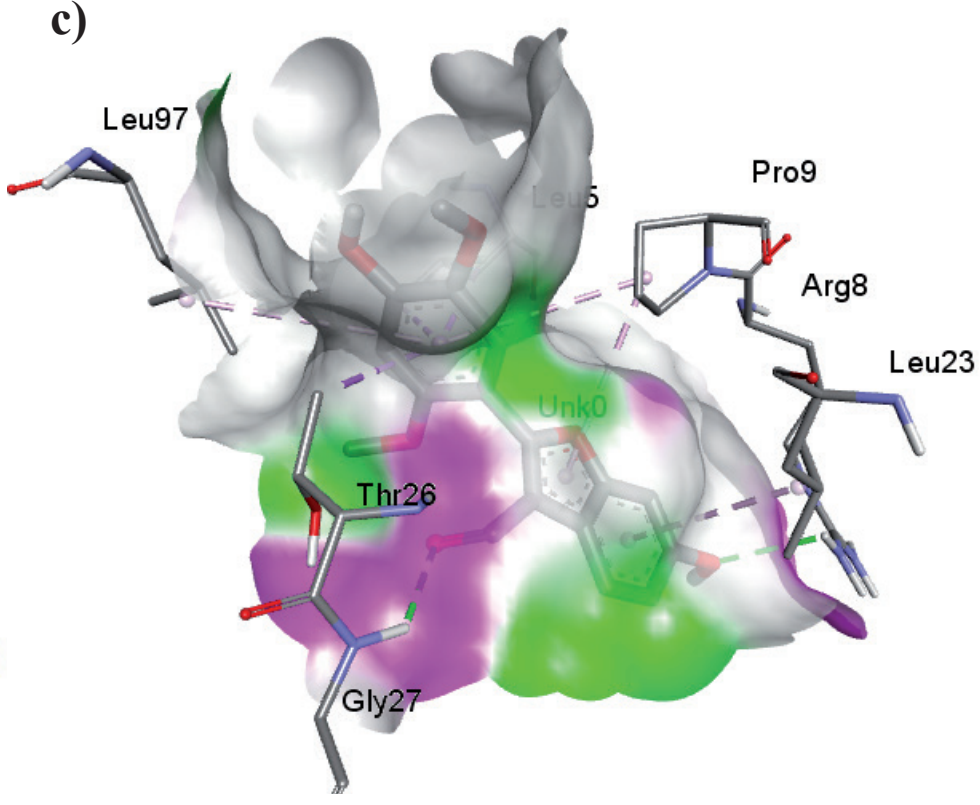

Figure 1. Interaction of (a) Cannflavin (b) AmyrisinC and (c) EryvarinP with HIV-1 Protease.

(alkaloid) [29], Mundulinol (flavonoid) [30] and Hydroxymunduserone (isoflavone) [31], etc. have also been reported in different studies exhibiting various medicinal effects. Hence, the phytochemicals with its immense potentials can be used in making novel drugs against various diseases.

In this study, different phytochemicals and their potential to be used as inhibitors against HIV-1 protease have been studied with the help of bioinformatics tools. Computer-aided software like Autodock tools, orca, Avogadro and pre-ADMET server were used to find the binding 
Table 2. Binding affinity, Ki values and DFT based analysis of phytochemicals against HIV-1 Protease (Based on docking results and ADMET)
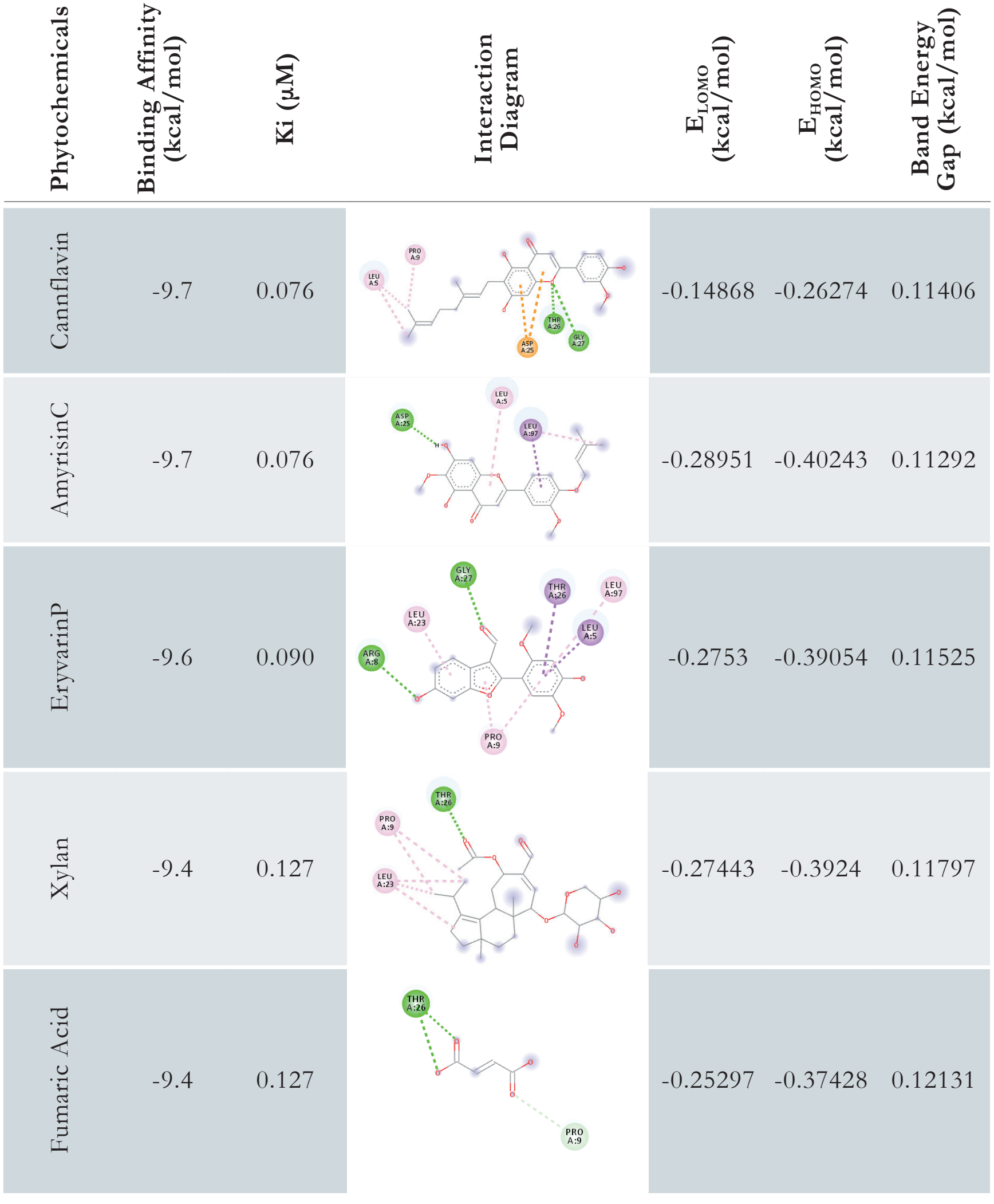


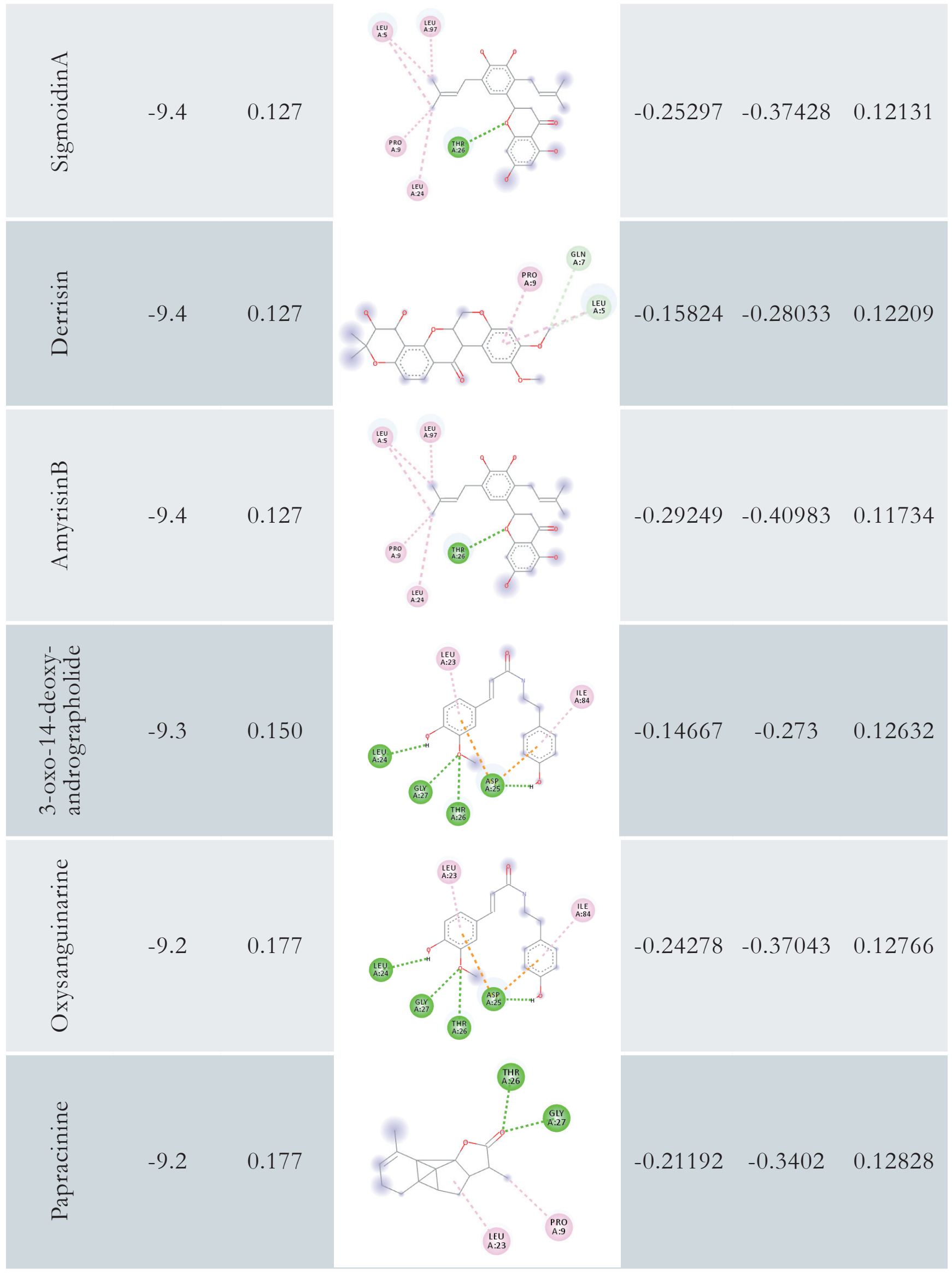




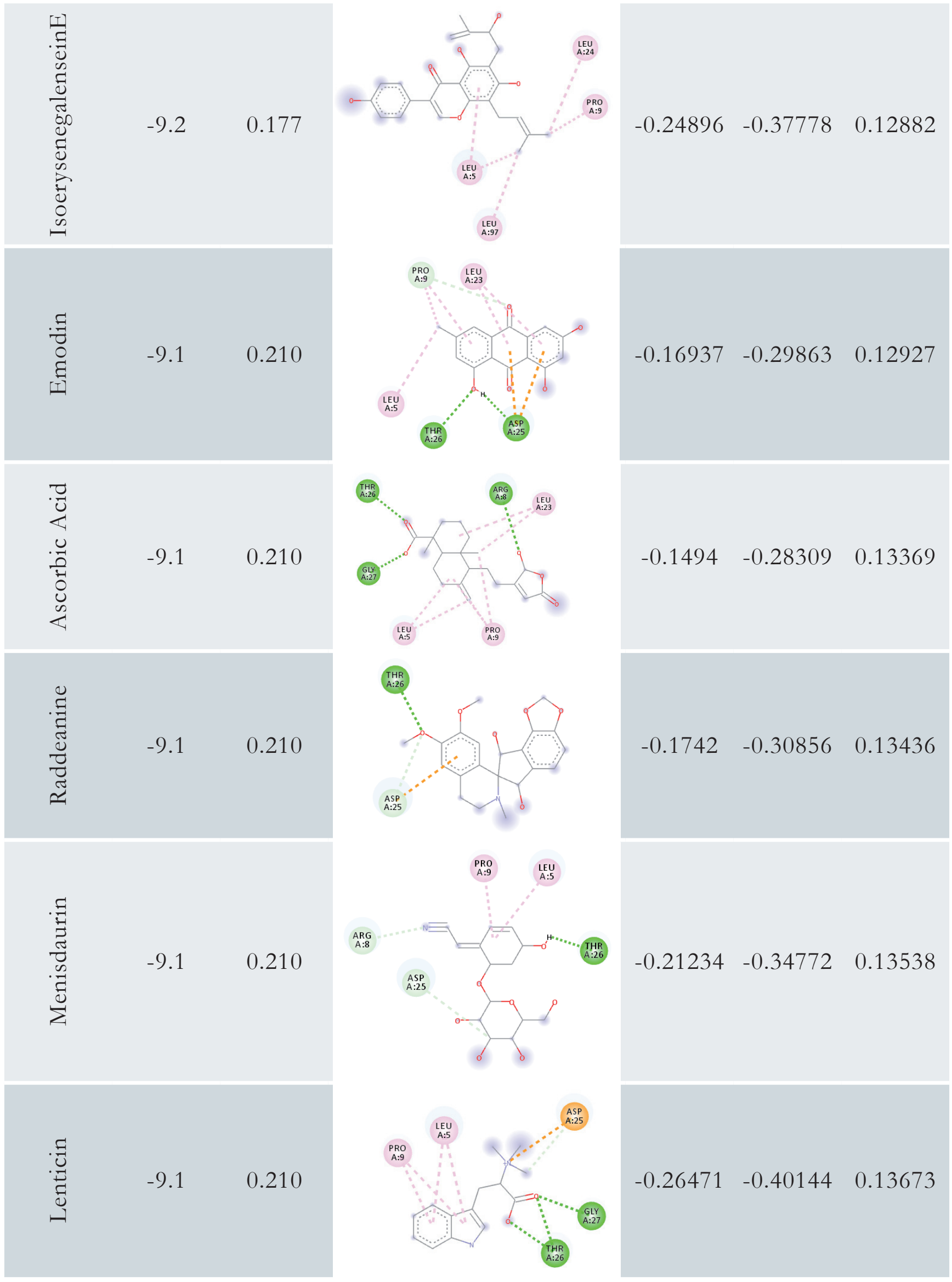




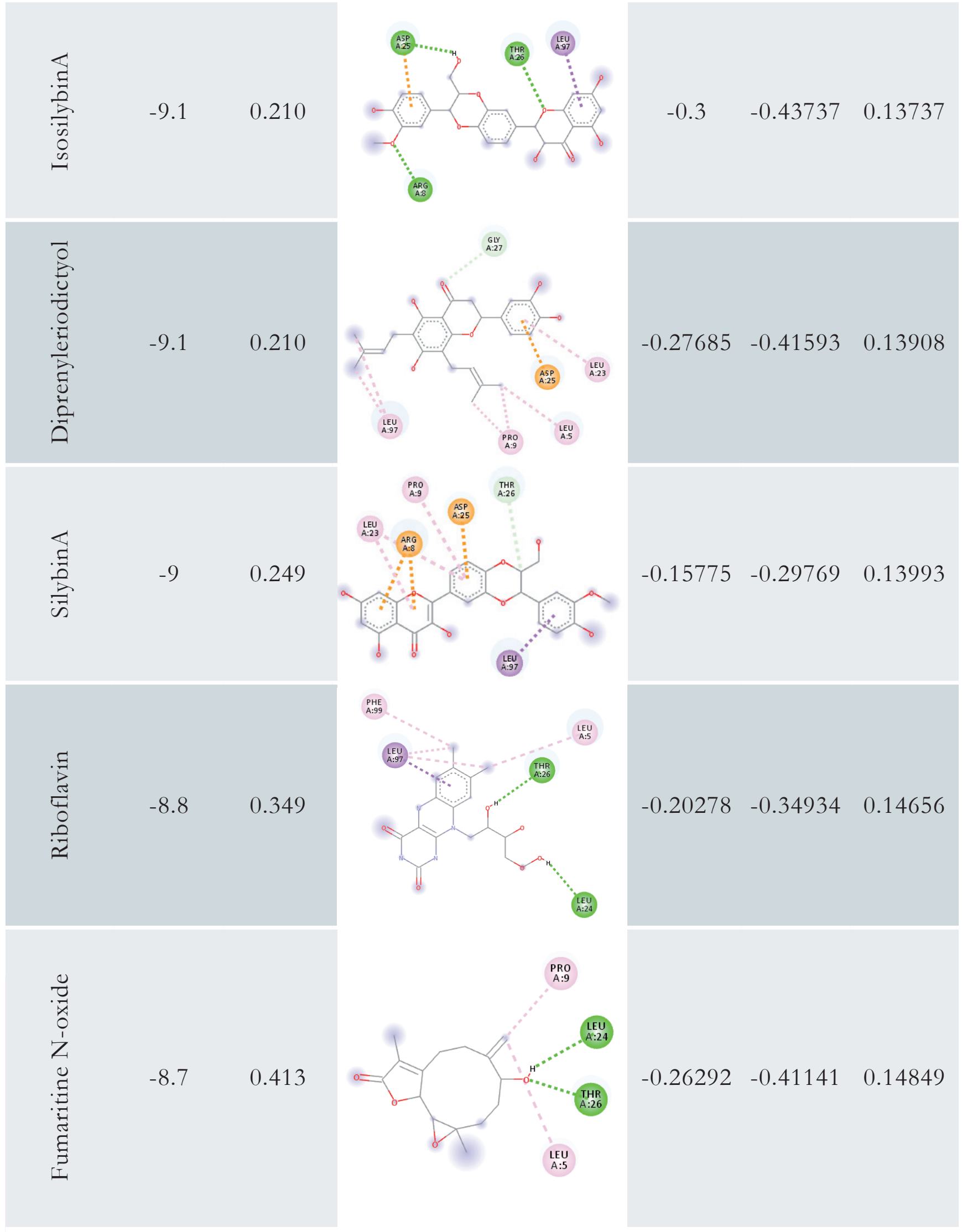




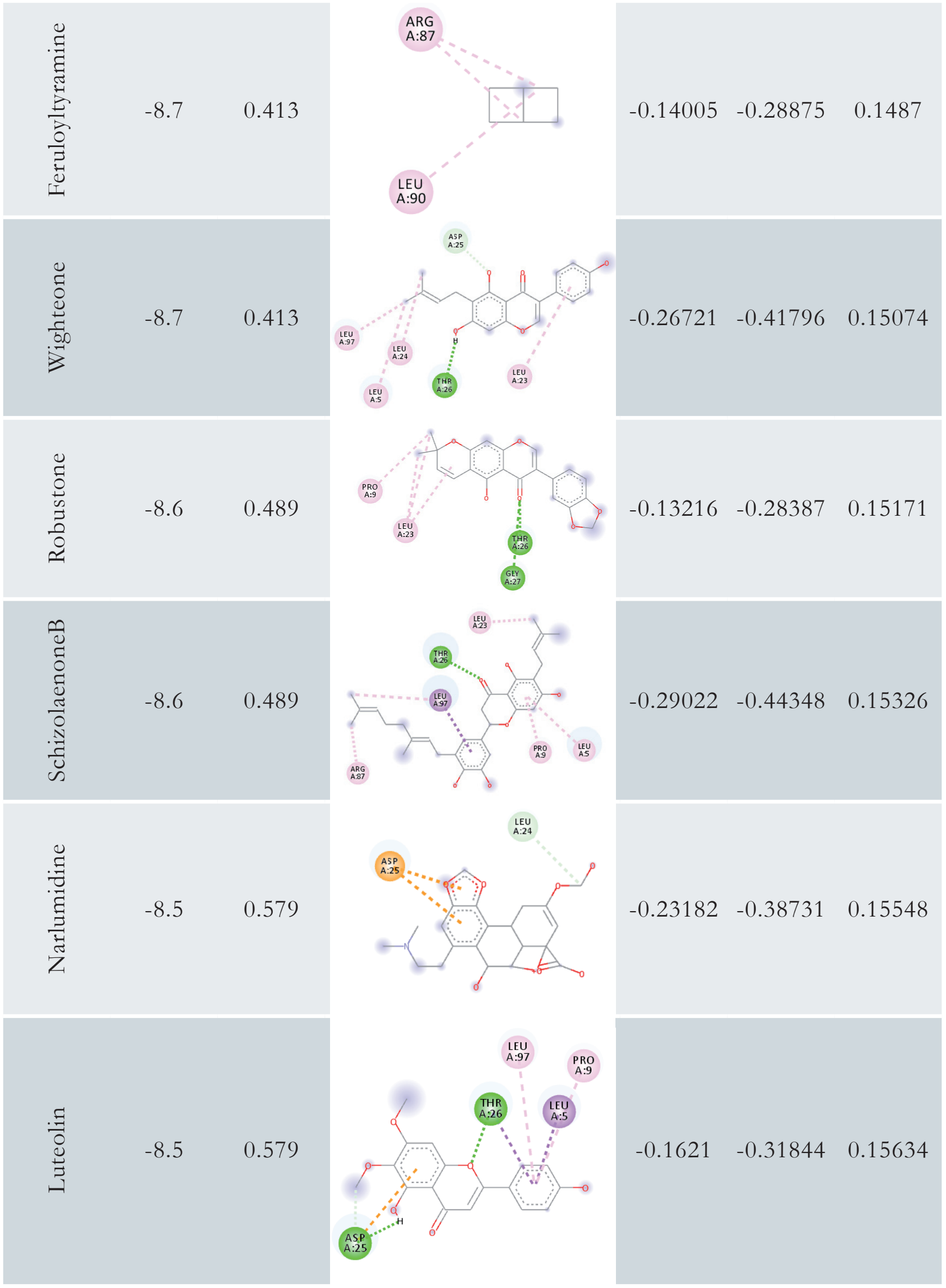




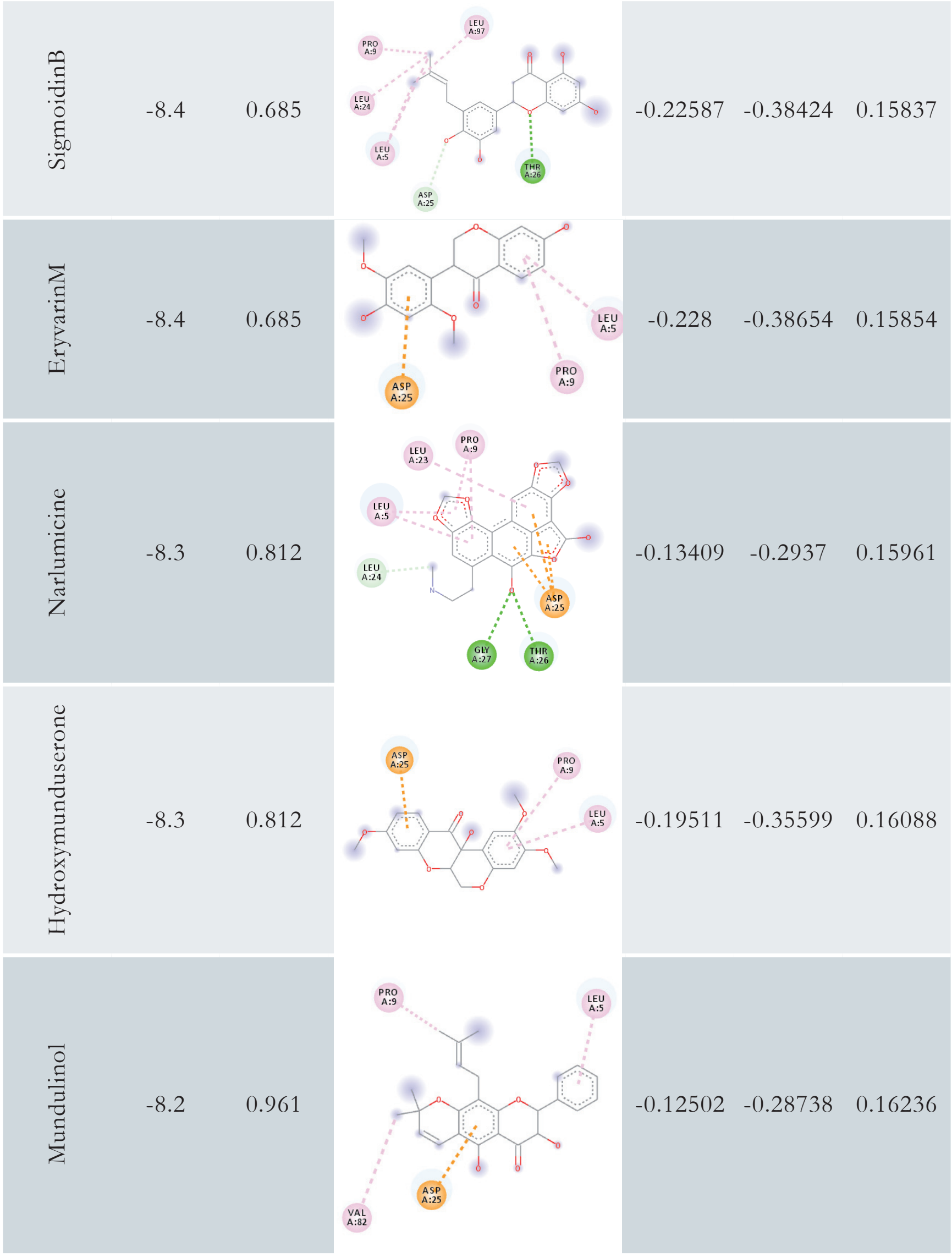




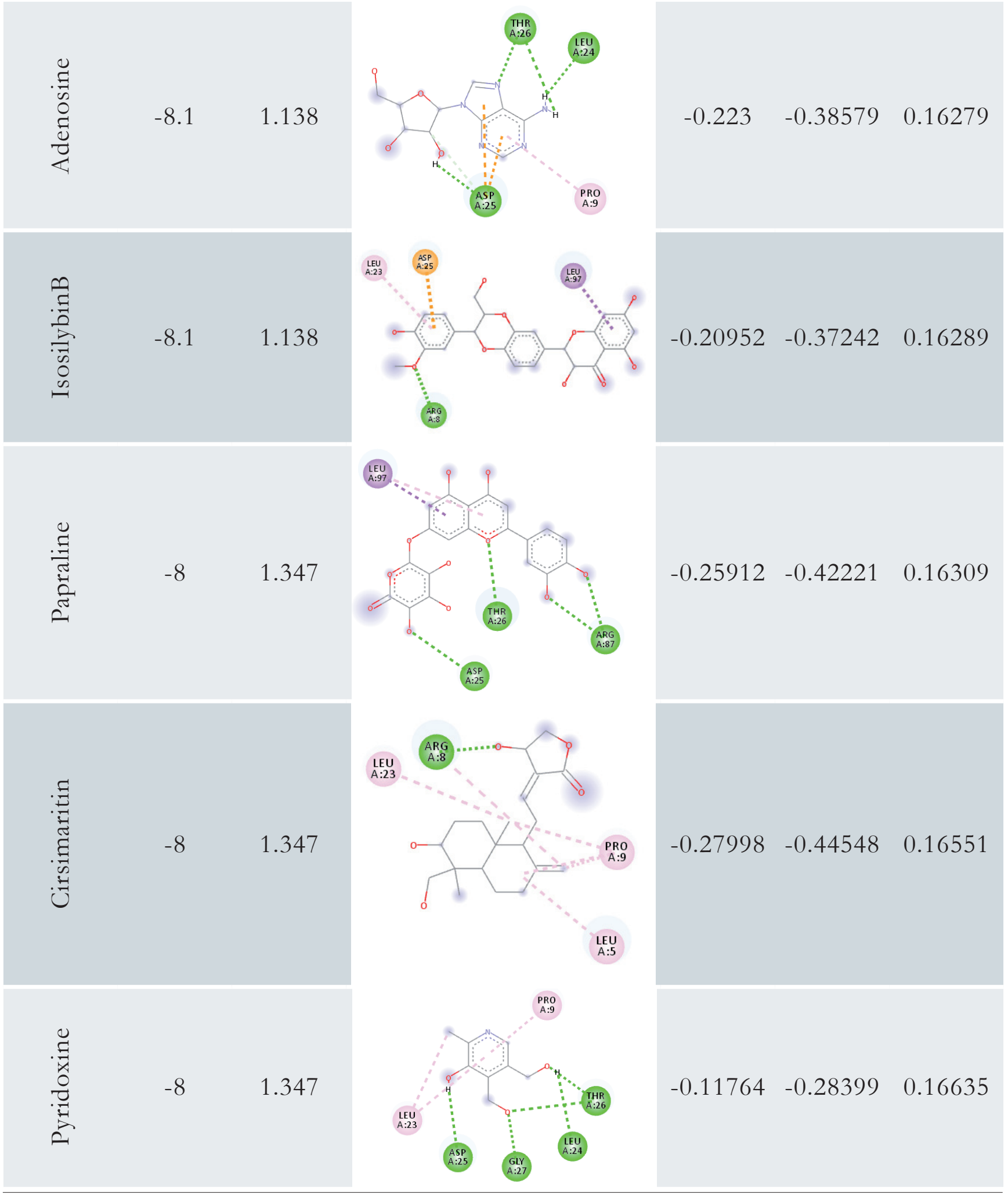

affinity, reactivity, ADMET properties of phytochemicals. These tools are really helpful for the in silico analysis of thousands of drugs and their pharmacological properties without the need of labs and the need of spending a lot of money on finding and extracting these desired derivatives from various plants [32]. 
$\mathrm{ADME} /$ tox properties are widely studied to determine that either the drug candidate will reach its targeted action site or not and any toxic effect of these compounds at its particular therapeutic dose. The drug-likeness properties and toxicity of these phytochemicals were checked with the help of an online bioinformatics tool, preADMET server [33]. In this study, pharmacokinetic properties of phytochemicals were effectively evaluated to prevent any associated side-effects in humans. The compounds which did not violate the Lipinski's rule of five were further screened. Lipinski rule consists of a set of five rules devised by Lipinski which predict the probability of failure or success of drug whether it is safe to be actively used as a human drug [34]. The drug should be orally available and the bio-availability of the drug will likely to happen if the drug candidate obeys 3 out of five rules of Lipinski, which are as followed: molecular weight should be below 500; there should be less than ten acceptor and not more than 5 donors of hydrogen bond; and the partition coefficient $(\operatorname{cog} \mathrm{P})$ should be below five [35]. Out of 2505 , a total of 108 compounds fulfilled the criteria provided by Lipinski's rule of 5. The ADME profile of these phytochemicals showed the potential of these compounds as drug candidates against HIV-1 protease.

The docking study was carried out to study the binding properties and interaction of these natural compounds on the active site of protease and to evaluate their inhibitory activity. The synthetic drugs like lopinavir, ritonavir and tipranavir, which have been used previously against HIV were also docked and compared with the phytochemicals. The comparison method was primarily adopted to determine the potentials of these phytochemicals to be used as HIV-1 protease inhibitors as compare to already available chemically synthesized drugs. After comparing, 38 compounds with binding affinity values ranging from -9.7 to $-8.0(\mathrm{kcal} / \mathrm{mol})$ were selected, greater than the highest binding affinity value exhibited by a synthetic compound lopinavir $(-7.9 \mathrm{kcal} / \mathrm{mol})$.

The DFT (density functional theory) is an in silico method based on quantum mechanics used to study the electronic structures. The DFT is one of the best methods to calculate the orbital energy values of various compounds [36]. In this study, the HOMO and LUMO energies were calculated. The energy difference between HOMO and LUMO is important for the stability of the structure and the difference is called the energy gap [37]. The energy gap of both the HOMO and LUMO energies indicates that the interactions taking place within a molecule due to charge transfer, particularly have an effect on the biological activity of the molecule [38]. If the energy gap between both the LUMO and HOMO is small as in the case of these phytochemicals $(0.112-0.166 \mathrm{kcal} / \mathrm{mol})$, it means that molecules reactivity is 
high. While the molecules exhibiting high energy gap means that reactivity is low [39].Therefore, the energy gap values of these molecules exhibited high potential to be used as novel drugs against HIV-1 protease.

\section{Conclusion}

Medicines produced through natural sources are of utmost importance, since from the past, medicines obtained through plants play a major contribution in providing a beneficial effect in many health-related problems. Until now, it has been proved that the plants have a huge potential and can be used in treating many deadly diseases. This study was aimed at targeting the HIV-1PR for discovering new drugs by using computer-aided methods. In this study, out of 2505 phytochemicals obtained from different plants having different medicinal properties, 108 compounds showed drug-likeness properties. After comparison with the synthetic drugs, 38 compounds were selected, the highest binding affinity value was $-9.7 \mathrm{kcal} / \mathrm{mol}$ shown by the Cannflavin against HIV-1 protease. The DFT analysis also further proved their high reactivity against HIV-1 protease, as the band energy values exhibited by these phytochemicals were the lowest $(0.112-0.166 \mathrm{kcal} / \mathrm{mol})$. These phytochemicals have the potential and can be used in the future for drug designing against HIV-1 protease.

\section{Conflict of interest}

The authors certify that they have no affiliations with or involvement in any organization or entity with any financial interest (such as honoraria, educational grants, participation in speakers membership, employment, consultancies, stock ownership, or other equity interest; and expert testimony or patent arrangements), or non (such as personal or professional relationships, affiliations, knowledge or beliefs) in the subject matter or materials discussed in this manuscript.

\section{References}

[1] Siuki HA, Peyman N, Vahedian-Shahroodi M, Gholian-Aval $M$, Tehrani H. Health education intervention on HIV/AIDS prevention behaviors among health volunteers in healthcare centers: An applying the theory of planned behavior, Journal of Social Service Research, 1-7, 2018.

doi: 10.1080/01488376.2018.1481177 
[2] Sobieski M, Przystupski D, Korzeniewska A, Kwiatkowski S, Górska A, Kotowski K, Baczyńska D. A review of current literature on the diagnosis, prophylaxis and treatment of HIV / AIDS, World Scientific News, 110: 129-146, 2018.

http://www.worldscientificnew .com/wp-content/uploads/2018/08/ WSN-110-2018-129-146-1.pdf

[3] Lawn SD, Butera ST, Folks TM.. Contribution of immune activation to the pathogenesis and transmission of human immunodeficiency virus type 1 infection, Clinical microbiology reviews, 14: 753-777, 2001.

doi: 10.1128/CMR.14.4.753-777.2001

[4] Fauci AS, Lane HC. Harrison's Internal Medicine, AccessMedicine, McGraw-Hill Education, New York, USA 2008.

[5] Joint United Nations Programme on HIV/AIDS, UNAIDS Data, 2017.

https://www.unaids.org/en/keywords/unaids-joint-united-nationsprogramme-hivaids

[6] Wlodawer A, Erickson JW. Structure-based inhibitors of HIV-1 protease, Annual review of biochemistry, 62: 543-585,1993.

doi: 10.1146/annurev.bi.62.070193.002551

[7] McQuade T, Tomasselli A, Liu L, Karacostas V, Moss B, Sawyer T, Heinrikson R, Tarpley W. A synthetic HIV-1 protease inhibitor with antiviral activity arrests HIV-like particle maturation, Science, 247: 454-456, 1990.

doi: 10.1126/science. 2405486

[8] Gulick RM, Mellors JW, Havlir D, Eron JJ, Gonzalez C, McMahon D, Richman DD, Valentine FT, Jonas L, Meibohm A. Treatment with indinavir, zidovudine, and lamivudine in adults with human immunodeficiency virus infection and prior antiretroviral therapy, New England Journal of Medicine, 337: 734-739, 1997.

doi: 10.1056/NEJM199709113371102

[9] Perelson AS, Essunger P, Cao Y, Vesanen M, Hurley A, Saksela K, Markowitz M, Ho DD. Decay characteristics of HIV-1-infected compartments during combination therapy, Nature, 387: 188, 1997.

doi: $10.1038 / 387188 \mathrm{a} 0$ 
[10] Clavel F, Hance AJ. HIV drug resistance, New England Journal of Medicine, 350: 1023-1035, 2004.

doi: 10.1056/NEJMra025195

[11] Veljkovic V, Mouscadet J-F, Veljkovic N, Glisic S, Debyser Z. Simple criterion for selection of flavonoid compounds with anti-HIV activity, Bioorganic \& medicinal chemistry letters, 17: 1226-1232, 2007.

doi: 10.1016/j.bmcl.2006.12.029

[12] Friedman SH, DeCamp DL, Sijbesma RP, Srdanov G, Wudl F, Kenyon GL. Inhibition of the HIV-1 protease by fullerene derivatives: model building studies and experimental verification, Journal of the American Chemical Society, 115: 6506-6509, 1993.

doi: $10.1021 / \mathrm{ja00068a005}$

[13] Condra JH, Schleif WA, Blahy OM, Gabryelski LJ, Graham DJ, Quintero J, Rhodes A, Robbins HL, Roth E, Shivaprakash M. In vivo emergence of HIV-1 variants resistant to multiple protease inhibitors, Nature, 374: 569-571, 1995.

doi: $10.1038 / 374569 \mathrm{a} 0$

[14] Lindegaard B, Keller P, Bruunsgaard H, Gerstoft J, Pedersen B. Low plasma level of adiponectin is associated with stavudine treatment and lipodystrophy in HIV-infected patients, Clinical \& Experimental Immunology, 135: 273-279, 2004.

doi: 10.1111/j.1365-2249.2004.02367.x

[15] Wiltink E. Antiviral drugs: present status and future prospects, The International journal of biochemistry, 26: 621-630, 1994.

doi: 10.1016/0020-711X(94)90161-9

[16] Tewtrakul S, Subhadhirasakul S, Puripattanavong J, and Panphadung T. HIV-1 protease inhibitory substances from the rhizomes of Boesenbergia pandurata Holtt, Songklanakarin Journal Science Technology, 25(4):503-508, 2003.

http://rdo.psu.ac.th/sjstweb/Volume.php?Vol=25-4

[17] Wadood A, Ghufran M, Jamal SB, Naeem M, Khan A, Ghaffar R. Phytochemical analysis of medicinal plants occurring in local area of Mardan, Biochemistry \& Analytical Biochemistry, 2: 1-4, 2013. doi: 10.4172/2161-1009.1000144 
[18] Hussain W, Qaddir I, Mahmood S, Rasool N. In silico targeting of non-structural 4B protein from dengue virus 4 with spiropyrazolopyridone: study of molecular dynamics simulation, ADMET and virtual screening, VirusDisease, 29(2):147-156, 2018.

doi: 10.1007/s13337-018-0446-4

[19] Rasool N, Ashraf A, Waseem M, Hussain W, Mahmood S. Computational exploration of antiviral activity of phytochemicals against NS2B/NS3 proteases from dengue virus, Turkish Journal of Biochemistry, 44: 1-17, 2018.

doi: 10.1515/tjb-2018-0002

[20] Delgado-Jaime MU, DeBeer S. Expedited analysis of DFT outputs: Introducing moanalyzer, Journal of computational chemistry, 33(27): 2180-2185, 2012.

doi: $10.1002 /$ jcc. 23028

[21] Tayade NT, Shende AT, Tirpude MP. DFT study of L-alanine's crystal, molecule and three linear molecules for optoelectronic behavior, International Journal of Scientific Research in Physics and Applied Sciences, 6(4): 23-27, 2018.

doi: 10.26438/ijsrpas/v6i4.2327

[22] Qaddir I, Rasool N, Hussain W, Mahmood S. Computer-aided analysis of phytochemicals as potential dengue virus inhibitors based on molecular docking, ADMET and DFT studies, Journal of vector borne diseases, 54(3): 255-262, 2017.

doi: 10.4103/0972-9062.217617

[23] Ramalingam M, Karthikeyan S, Kumar D. Docking Studies of HIV-1 Protease with Phytochemicals from Mappia Foetida, International Journal of Computer Applications, 43(4): 16-22, 2012.

doi: $10.5120 / 6091-8272$

(https://www.ijcaonline.org/archives/volume43/number4/6091-8272)

[24] Senthilvel P, Lavanya P, Kumar KM, Swetha R, Anitha P, Bag S, Sarveswari S, Vijayakumar V, Ramaiah S, Anbarasu A. Flavonoid from Carica papaya inhibits NS2B-NS3 protease and prevents Dengue 2 viral assembly, Bioinformation, 9(18): 889-895, 2013.

doi: 10.6026/97320630009889 
[25] Ibrahim AK, Radwan MM, Ahmed SA, Slade D, Ross SA, ElSohly MA, Khan IA. Microbial metabolism of cannflavin A and B isolated from Cannabis sativa, Phytochemistry, 71: 1014-1019, 2010.

doi: 10.1016/j.phytochem.2010.02.011

[26] Barros IBd, Daniel JFdS, Pinto JP, Rezende MI, Braz Filho R, Ferreira DT. Phytochemical and antifungal activity of anthraquinones and root and leaf extracts of Coccoloba mollis on phytopathogens, Brazilian Archives of Biology and Technology, 54(3): 535-541,2011.

doi: 10.1590/S1516-89132011000300015

[27] Sagbo IJ. Phytochemical analysis and antibacterial properties of aqueous and ethanol extracts of brachylaena elliptica (thurb.) dc. and brachylaena ilicifolia (lam.) phill. \& schweick, Master of Science: Biochemistry Dissertation, University of Fort Hare, 2015.

https://core.ac.uk/download/pdf/145051887.pdf

[28] Murphy BT, Cao S, Norris A, Miller JS, Ratovoson F, Andriantsiferana R, Rasamison VE, Kingston DG. Cytotoxic flavanones of Schizolaena bystrix from the Madagascar rainforest, Journal of natural products, 68(3): 417-419, 2005.

doi: $10.1021 / \mathrm{np} 049639 \mathrm{x}$

[29] Rao C, Verma A, Gupta P, Vijayakumar M. Anti-inflammatory and anti-nociceptive activities of Fumaria indica whole plant extract in experimental animals, Acta Pharmaceutica, 57(4): 491-498, 2007.

doi: 10.2478/v10007-007-0039-z

[30] Pezzuto JM, Beecher C, Fong H, Farnsworth NR, Mehta RG, Moon RC, Hedayat S, Udeani GO, Moriarty R, Kinghom A. Discovery and characterization of natural product cancer chemopreventive agents, Atta-ur-Rabman and M. Iqbal (eds.), New Trends in Natural Product Chemistry, Harwood Academic Publishers: Chur, Switzerland: 95-107,1998.

[31] Wu X, Liao H, Wu K, Cui L. Chemical constituents from the seeds of Amorpha fruticosa and their chemotaxonomic significance, Open Access Library Journal, 3: 1-7, 2016.

doi: 10.4236/oalib.1102740 
[32] Lagunin AA, Goel RK, Gawande DY, Pahwa P, Gloriozova TA, Dmitriev AV, Druzhilovsky DS. Chemo-and bioinformatics resources for in silico drug discovery from medicinal plants beyond their traditional use: a critical review, Natural product reports, 31: 1585-161, 2014.

doi: $10.1039 / \mathrm{c} 4 \mathrm{np} 00068 \mathrm{~d}$

[33] Wishart DS. Online Databases and Web Servers for Drug Metabolism Research. Edited by Johannes Kirchmair, Wiley Publishers, New Jersey, US, 2014.

[34] Lipinski CA, Lombardo F, Dominy BW, Feeney PJ. Experimental and computational approaches to estimate solubility and permeability in drug discovery and development settings, Advanced drug delivery reviews, 46(1-3): 3-26, 2001.

doi: 10.1016/S0169-409X(00)00129-0

[35] Duchowicz PR, Talevi A, Bellera C, Bruno-Blanch LE, Castro EA. Application of descriptors based on Lipinski's rules in the QSPR study of aqueous solubilities, Bioorganic \& medicinal chemistry, 15(11): 3711-3719, 2007.

doi: 10.1016/j.bmc.2007.03.044

[36] Kavitha R, Karunagaran S, Chandrabose SS, Lee KW, Meganathan C. Pharmacophore modeling, virtual screening, molecular docking studies and density functional theory approaches to identify novel ketohexokinase (KHK) inhibitors, Biosystems, 138: 39-52, 2015.

doi: 10.1016/j.biosystems.2015.10.005

[37] Sakkiah S, Lee KW. Pharmacophore-based virtual screening and density functional theory approach to identifying novel butyrylcholinesterase inhibitors, Acta Pharmacologica Sinica, 33: 964-978, 2012.

doi: $10.1038 /$ aps.2012.21

[38] Sathyanarayanmoorthi V, Karunathan R, Kannappan V. Molecular modeling and spectroscopic studies of Benzothiazole, Journal of Chemistry, 2013: 14, 2013.

doi: 10.1155/2013/258519

[39] Queiroz AN, Gomes BA, Moraes Jr WM, Borges RS. A theoretical antioxidant pharmacophore for resveratrol, European journal of medicinal chemistry, 44(4): 1644-1649, 2009.

doi: 10.1016/j.ejmech.2008.09.023 


\section{Búsqueda de propiedades farmacológicas de unión y reactividad de fitoquímicos selectivos con potencial inhibidor de la proteasa VIH-1}

Resumen: La proteasa del VIH-1 juega un papel esencial en el ciclo de replicación del VIH-1; por tanto, existe una necesidad directa de desarrollar nuevos inhibidores de la proteasa del VIH-1, con los que se pueda detener la replicación viral. El presente estudio apunta al descubrimiento de inhibidores potenciales de la proteasa del VIH-1 a partir de un conjunto de fitoquímicos. A partir de 2505 fitoquímicos, se acoplaron 108 compuestos, después del tamizaje, para analizar su potencial inhibitorio contra la proteasa del VIH-1. Se llevó a cabo también un análisis DFT para estudiar la reactividad de compuestos fuertemente acoplados. De los 108 fitoquímicos evaluados, 38 compuestos mostraron afinidad de unión mayor que la del umbral deseado. Los resultados del análisis DFT mostraron que la reactividad de esos 38 inhibidores fue también alta, comparada con otros compuestos. Estos resultados sugieren que los 38 fitoquímicos seleccionados son candidatos a medicamentos, y tienen potencial para ser usados con efectividad contra el VIH en el futuro.

Palabras clave: VIH-1; proteasa; fitoquímicos; acoplamiento molecular; DFT; ADMET. 


\section{Examinando as propriedades de ligaçáo farmacológica e reatividade de fitoquímicos seletivos como potenciais inibidores de protease HIV-1}

Resumo: A protease HIV-1 possui um papel essencial no ciclo de replicação do HIV-1, havendo, portanto, uma necessidade direta de desenvolver novos inibidores de protease HIV-1, os quais podem cessar a replicação viral inibindo a protease. O presente estudo visa a descoberta de potenciais inibidores de protease HIV-1 a partir de um conjunto de fitoquímicos. De 2505 fitoquímicos, 108 compostos foram analisados por docking após uma triagem com protease HIV-1 para avaliar seu potencial de inibição frente a protease. Também foi realizada análise por DFT para estudar a reatividade dos compostos que presentaram forte acoplamento. Dos 108 fitoquímicos, 38 compostos apresentaram afinidade de ligação maior ao limite desejado. A reatividade de estes 38 inibidores também foi elevada quando comparada a outros compostos, baseado nos resultados por DFT. Estes resultados sugerem que os 38 fitoquímicos selecionados poderiam ser candidatos a fármacos, com potencial eficiência frente a HIV no futuro.

Palavras-chave: HIV-1; protease; fitoquímicos; docking molecular; DFT; ADMET. 


\section{Ammara Akhtar}

Is a Biotechnologist at University of Management and Technology, Lahore, Pakistan. Her research areas include Enzymology, Computational Biology and Drug Discovery.

ORCID: 0000-0002-3497-5004

\section{Waqar Hussain}

Received the MS degree in Computer Science from the University of Management and Technology (UMT), Lahore, Pakistan. He is currently working as a research associate at National Center of Artificial Intelligence, Punjab University College of Information and Technology, University of the Punjab, Lahore, Pakistan. His current research interests include Bioinformatics, Computational Biology, Computer Aided Analysis, Pattern Recognition and Machine Learning.

ORCID: 0000-0001-8991-9424

\section{Nouman Rasool}

Has earned the PhD degree in Biochemistry from the School of Biological Sciences, University of the Punjab, Lahore, Pakistan. He is currently working at Dr Panjwani Center for Molecular Medicine and Drug Research, International Center for Chemical and Biological Sciences, University of Karachi. His research areas include Protein Chemistry, DNA Forensics, Enzymology, Computational Biology and Drug Discovery.

ORCID: 0000-0003-0210-5845 